\title{
İslâm Hukuku ve Pozitif Hukuk Açısından Çocukta Ceza Ehliyeti
}

\author{
Murat Şimşek*
}

\begin{abstract}
Öz: Her ilim dalı kendi kural ve amaçları doğrultusunda insan hayatını birçok devreye ayııırken, İslâm hukukçuları da terettüp eden hak ve sorumluluklar açısından kişiyi devrelere ayırmışlar; bu ayrımlarda ölçüt olarak fiziki ve aklî olgunlaşma süreçlerini göz önünde bulundurmuşlardır. İslâm hukuk usulünün inceleme alanında yer alan ehliyet bahsinin büyük bir kısmının, çocukluk dönemi ile ilgili olduğu görülmektedir. Kişiyi hak ve sorumluluklara ehil kılan hukukî bir vasıf olan ehliyet, temelde haklardan istifade (vucûb) ehliyeti ve de hakları kullanabilme (edâ) ehliyeti şeklinde ikiye ayrılmaktadır. Bu ehliyetler içerisinde önemli unsurlardan biri ise ceza ehliyetidir. Çocuğun ceza ehliyetine ehil olup olmadığı, hangi yaştan itibaren cezâi sorumlulukla muhatap olacağı, bu sorumluluğun hangi tür müeyyideleri içereceği vb. sorular konunun temelini teşkil eder. Pozitif hukukta da İslâm Hukuku'na benzer yaklaşımlar benimsenmiş, kendi haklarını henüz koruyamayacak durumda olan çocuklar için lehlerine bazı düzenlemelere gidilmiştir. Konuyla ilgili literatüre bakıldığında çocuğun ceza ehliyeti ile ilgili doğrudan araştırma sayısının gayet sınırlı olduğu görülmektedir. Osmanlı dönemi uygulamalarında kanunnamelerden Mecelle ve Hukuk-ı Aile Kararnâmesi'ne kadar gelişen süreçte çocuğun ehliyeti ile ilgili çalışmalar aynı zamanda ceza ehliyetine de ışık tutmaktadır.
\end{abstract}

Anahtar Kelimeler: Çocuk, Ehliyet, Ceza, Temyiz, İslâm Hukuku, Osmanlı.

\begin{abstract}
Just as every branch of science is devoted to various aspects of human life according to its own rules and purposes, Islamic jurists have devoted themselves to the aspects of human life regarding rights and responsibilities and have considered these distinctions to be a process of physical and mental maturity. In Islamic Law, among the most hotly debated issues is in the domain of individual responsibility of which the majority of this issue relates to the child. The concept of ahliyah (license) is a qualification of a person who is competent in his understanding of legal rights and responsibilities. Ahliyah is divided into two parts: (1) the license to benefit from one's rights (wucūb) and (2) the license to make use of one's rights (edā). Among the questions dealt with in this issue are whether a child is competent in his understanding of criminal license, a case that deals with the age which criminal responsibility begins, what responsibilities are included, and what type of sanctions are applied. Islamic law has also adopted similar approaches as has modern positive law. In the two legal systems there are certain regulations in favor of children who have yet to attain the conscious or ability to preserve their rights. It is seen while looking at the present literature written on this matter that direct research regarding a child's criminal ahliyah is limited to a very small amount. Taking a look at Ottoman applications of these issues, such as the Majallah and Huqūq-ı Aile Qararnāmesi, will help to shed light on the issues presented in the subject..
\end{abstract}

Keywords: Child, Ahliyah (license), Criminal Responsibility, Criminal Liability, Appeal, Islamic Law, Ottoman.

* Yrd. Doç. Dr., Çanakkale Onsekiz Mart Üniversitesi Ilahiyat Fakültesi İslam Hukuku Anabilim Dalı Öğretim Üyesi. Illetişim: muratsimsek@comu.edu.tr, Çanakkale Onsekiz Mart Üniversitesi Ilahiyat Fakültesi Terzioğlu Yerleşkesi, Çanakkale.

AtıfO: Şimşek, M. (2012). İslâm hukuku ve pozitif hukuk açısından çocukta ceza ehliyeti. Insan ve Toplum, 2 (3), 139-164. 


\section{Giriş}

İslâm, öncelikle insanın yaşama hakkını kutsal saymış, bununla beraber mülkiyet, özel hayatın dokunulmazlığı gibi birçok hakkı da korunması gereken değerler olarak belirlemiş̧ir. İslâm hukuk literatüründe bu, İslâm'ın korunmasını ilke olarak belirlediği vazgeçilmez beş hak (zarûriyyâtı hamse) olarak belirtilmiştir ki bunlar; din, can, akıl, nesil ve malın korunmasını ifade eder. İslâm, bu haklara karşı işlenecek suçlara birtakım cezâî müeyyideler öngörmüştür. İşte bu çerçevede, hakları ihlal eden ile hakkı ihlal edilenin yaşını dikkate alan bazı özel hükümler koyulmuştur.

Bu çalışmada, çocukta ceza ehliyetinin başlangıç ve gelişimi üzerinde durulacak, tarihî süreçteki uygulamalara kısa telmihler yapılarak son dönemdeki bazı uygulamalara işaret edilecektir. Ayrıca Türk Ceza Kanunu'ndaki hükümlere de değinilecektir.

Konuyla ilgili literatüre kısaca temas etmek gerekirse, çocukta ceza ehliyeti konusuyla doğrudan ilgili şamil bir kaynak ve araştırmaya tarafımızdan rastlanılamamıştır. Ancak, konu, öncelikle fıkıh usulü literatüründe hüküm bahsinin alt bölümü olan ehliyet bahislerinde, füru fıkıh literatüründe ise borçlar hukuku alanındaki hacir, me'zûn vb. konularla nikah-talak, hidâne ve nesep gibi aile hukuku konularında, bir de ceza hukukuyla ilgili bölümlerde dağınık ve sınırlı olarak yer almaktadır. Muasır dönemdeki müstakil bazı çalışmalarda ise doğrudan bu meseleyi ele almamakla birlikte ehliyet, ceza ve suçlar üzerine yapılan araştırmalarda, özetle çocuk ve çocuğun ceza ehliyeti meselesine yer verildiği görülmektedir.

Bütün bunlarla birlikte İslâm hukuk tarihî içerisinde doğrudan çocuk ile ilgili hükümleri içermekle beraber az da olsa cezâi ehliyet konusuna değinen bir çalışma olan, Mecdüddîn Üsrûşenî'nin (ö. 632/1235) Câmi'u ahkâmi's-sığâr (I-II, Kahire, ts.) adlı eseri zikre değerdir. Günümüzde konuyla doğrudan ilgili olarak yapılmış en önemli çalışma, Ankara Üniversitesi Hukuk Fakültesi'nde Eylem Ümit tarafından hazırlanan "Kentte Suça Karışmış Çocuklarda Toplumsal Ortam ve Ceza Ehliyeti Araştırmaları" adlı doktora çalışmasıdır. Çalışma, hukuk tarihî açısından çocuğun ceza ehliyeti ile ilgili yaklaşımlar ve gerekçeleri üzerinde yeterli sayılabilecek miktarda durmaktadır. Konuyla doğrudan ilgili bir diğer çalışma, Naci Şensoy tarafından kaleme alınan "Eski Devirlerde ve İslâm'da Yaşın Cezaî Mesuliyet Üzerindeki Tesiri" adlı makaledir. Konuyla doğrudan ilgili en yeni çalışma ise Mücahit Çolak tarafından kendisine ait doktora çalışmasından istifadeyle hazırlanmış bulunan "İslâm Hukuku'nda Ceza Ehliyeti Açısından Yaş Küçüklüğü" adlı makaledir. Ayrıca çocukta ceza ehliyeti konusuna dolaylı olarak değinen bazı araştırmalar da mevcuttur. Yine Mücahit Çolak'ın hazırlamış olduğu "i̇slâm Hukuku'nda Ceza Ehliyetini Etkileyen Durumlar" adlı doktora çalışması ile Talip Atmaca tarafından hazırlanan "İslâm Hukuku'nda Ceza Ehliyeti” adlı doktora tezi, ilgili bölümlerinde çocukta ceza ehliyeti konularına değinmektedirler. Ayrıca Ümit Karslı tarafından hazırlanan "Mezheplere Göre Ceza Ehliyeti ve Günümüz Hukukuyla Mukayesesi" adlı 
yüksek lisans tezi konuyla dolaylı olarak ilgili bir çalışma olarak zikredilebilir. Muasır dönemde Arap âleminde konuyla dolaylı yönden ilgili birkaç çalışmadan bahsetmek gerekirse, bunlar arasında Kubeysî'nin, es-Sağîr beyne ehliyyeti'l-vucûb ve ehliyyeti'ledâ adlı araştırmasıyla, Hüseyin Tevfik Rıza'nın, Ehliyyetü'I-'ukûbe fi'ş-şerî'ati'l-İslâmiyye ve'l-kânûni'l- mukâran adlı eseri ve Cebûrî'nin, Avârıdu'l-ehliyye 'inde'l-usûliyyîn adlı çalışmasını saymak mümkündür.

Verilen bilgilerden de anlaşılacağı üzere çocuğun ceza ehliyeti ile ilgili doğrudan araştırma sayısı gayet sınırlıdır. Dolayısıyla bu çalışmada amaç, konunun doğrudan araştırılmasının gereğine işaret ederek meselenin önemine dikkat çekmek ve de konuyla doğrudan ilgili bölümler üzerinde durmaktır.

\section{Hukukta Çocuk (Küçük) Terimi}

Çocukluk, ilk bebeklikten on sekiz yaşına kadar geniş bir dönemi kapsar ve bu uzun süre çeşitli ihtiyaçları, yetenekleri ve potansiyelleri içerir (Franklin, 1993, s. 22). Çocuk kavramı, her hukuk dalında içerik bakımından farklı değerlendirilmektedir. Gerek fail, gerekse suçun mağduru olma yönünden çocuk, Türk Ceza Kanunu'nda (TCK) şu şekilde tanımlanmıştır: "Çocuk deyiminden; henüz on sekiz yaşını doldurmamış kişi" (md. 6.-(1)... (b)) anlaşılır. Bu tanıma göre bir suçun sanığı ya da mağduru 18 yaşını fiilen doldurmamış yani 19 yaşından gün almamış ise çocuk olarak değerlendirilmektedir (Şafak, 2005, s. 326). Uluslararası bildiri ve sözleşmeler arasında Pekin kurallarındaki çocuk tanımı, cezaî ehliyeti esas alarak yapılmış bir tanım olarak göze çarpmaktadır. Buna göre: "Işledikleri suçlar açısından, kendi hukuk sistemlerine göre yetişkinlerden farklı bir tarzda muameleye tabi tutulan kimseye çocuk veya genç denir" (Okumuş, 2005, s. 402).

Çocukluğun sona eriş yaşı ülkelere göre değişiklik göstermektedir. Bazı ülkelerde 15, bazılarında ise 18 ya da 21 olarak belirlenmiştir. Kanunun çocuk için maksimum ve minimum bir yaş hududu tayin etmesi, çocuğa uygulanacak ceza ve tedbirlerin yerine getirilmesi için belirlenmesi, zorunlu bir kriterdir (Yelesdağ, 2006, s. 4). Bu farklılıkların birçok sebebi bulunmalıdır. Toplumların tarihî tecrübeleri, sosyal yapıları, aile ve çocuk algıları, kabul ettikleri hukuk sisteminden kaynaklanan tercihler, dinî bazı mülahazalar ve çağdaş birtakım tecrübeler bunda etkili olmuş olabilir.

Dünyanın çeşitli ülkelerinde sorumsuzluk çağının sınırı iki ayrı esasa göre düzenlenmiştir: Birinci yaklaşımda sorumsuzluk çağının kesin bir şekilde kanunda belirtilmesi ön görülmüştür. Mesela Fransa'da 18, İsviçre, İtalya ve Almanya'da 14, Bulgaristan'da 13, İspanya'da 16, Danimarka ve Finlandiya'da 16 yaş olarak kabul edilmiştir. İkincisi ise sorumsuzluk çağının sınırını belirleme yetkisini hâkime vermeyi ön gören yaklaşımdır. Bu sistem, cezâî rüşt yaşını doldurduğu halde tam olgunlaşmamış gençlerin durumunu gözetmeye yönelik çabayı göstermektedir. (Dönmezer-Erman, 1999, s. II, 729). 
İslâm Hukuku'nda doğumla başlayan ve ergenlik çağına kadar devam eden döneme çocukluk, bu dönemi yaşayan kimseye ise çocuk denir (Ali Haydar, 1330, s. III, 9; Aydın, 1993, s. VIII, 361). İslâm Hukuku'nun kanunlaştırılmış bir metni olan Mecelle'de çocukluk dönemi, iki ana bölüme ayrılarak şöyle tanımlanmıştır: "Sagîr-i gayr-i mümeyyiz: Bey' ve şirâyı fehm etmeyen, yani mülkiyet-i bey'in sâlib ve şirânın câlib olduğunu bilmeyen ve onda beş aldanmak gibi, gabn-i fâhiş olduğu zâhir olan bir gabni, gabn-i yesîrden temyiz ve tefrik eylemeyen çocuk olup, bunları temyiz eden çocuğa, sagîr-i mümeyyiz denilir." (Mecelle, md. 943). İslâm hukuku birçok konuda tam ehliyetli sayılmak için büluğ çağına erişmiş olmayı, bir diğer ifadeyle cinsel açıdan gelişmiş olmayı yeterli saymış ise de her bünye ve yaşın biyolojik gelişme hızı aynı olmayıp biyolojik gelişmeyi açık ve kabul edilebilir bir dış gelişmeye bağlama zarureti ortaya çıkmıştır. Cinsel gelişimin yanı sıra İslâm Hukuku'nda belli bir fikrî olgunluk seviyesine erişmiş olmanın arandığı durumlar da söz konusudur (Erbay, 1998, s. 4-5). Özellikle temyiz ve rüşt ile ilgili ayrım noktaları, bunu göstermektedir.

Hukukî anlamda şahsiyetin ilk dönemlerini ifade eden küçüklük (çocukluk) dönemi, doğal olarak şahsiyetle birlikte başlar. İslâm Hukuku'nda ise şahsiyet, sağ doğmak şartıyla ceninin ana rahmine düşmesiyle başlamaktadır. (Erbay, 1998, s. 5; Medkûr, 1969, s. 127-128). Türk Medenî Kanunu'na (TMK) göre de şahsiyet (kişilik), çocuğun sağ olarak tamamıyla doğduğu anda başlar ve ölümle sona erer. Çocuk, sağ doğmak koşuluyla, ana rahmine düştüğü andan itibaren bir kısım haklara ehil hale gelir (md. 28). Dolayısıyla TMK'daki hükmün, İslâm Hukuku'yla bir paralellik arz ettiği görülmektedir.

Kur'ân-ı Kerîm'de geçen bir ayetten anlaşıldığına göre, kişinin bazı mâlî tasarruflarına engel teşkil eden küçüklüğün, cinsel erginlik çağına ulaşmayla yani ayette geçen ifadesiyle evlilik çağına erişmeyle sona ereceği ifade edilmektedir. İlgili ayet, şu şekildedir: "Evlilik çağına gelinceye kadar yetimleri (gözetip) deneyin, eğer onlarda akılca bir olgunlaşma (rüşt) görürseniz hemen mallarını kendilerine verin" (Nisa 4/6). Ayette, her ne kadar çocuğun mâlî tasarrufa ehil olabilmesi için ayrıca rüşt sahibi (reşit) olmasının şart koşulduğu görülüyorsa da cinsel olgunlaşmanın da bu konuda önemli bir ölçü olduğu zikredilmektedir.

İslâm hukuk doktrininde cinsel olgunluğun alameti olarak cinsiyeti erkek olan küçükler için ihtilam ve ihbâl (gebe bırakabilme), cinsiyeti kız olan küçükler bakımından ise hayız (âdet görme) ve habl (gebe kalabilme) kriter olarak benimsenmiştir. Nitekim Mecelle de bu anlayışı koruyarak kanunlaştırmıştır. (Hadd-i bülûğ, ihtilâm ve ihbâl yani gebe eylemek ve hayız ve habl yani gebe olmak ile sabit olur, md. 985). Ancak, ölçü alınan bu alametlerin cinsiyete, bölgelere, iklimlere ve yetişme şartlarına göre değişiklik arz ettiği görülmüş, bu sebeple de büluğ için asgarî ve azami yaş hadleri belirleme yoluna gidilmiştir (Erbay, 1998, s. 6-7; İbnü'l-Kayyim, 1983, s. 232-233). Nitekim bu husus, Osmanlı dönemi kanunlarına da yansımıştır. Mesela Mecelle, "Sinn-i bulûğun (büluğ yaşının) mebdei erkekte tam 12, kızda 9 yaştır." (md. 986) derken yine 1917 Osmanlı 
Hukuk-ı Aile Kararnamesi, "12 yaşını itmam etmemiş (tamamlamış) olan sağîr (küçük) ile 9 yaşını itmam etmemiş olan sağîre (küçük kız), hiç kimse tarafından tezvic edilemez (evlendirilemez)" (md. 7) derken asgarî büluğ yaşına işaret etmiştir.

Büluğ yaşının üst sınırı konusunda ise doktrinde bir görüş birliği olmadığı görülmektedir. Çoğunluğun benimsediği görüşe göre, kız ve erkekler için büluğ yaşının üst sınırı, 15 yaşın bitimidir. Nitekim Mecelle, "Sinn-i bulûğun mebdei erkekde tam on iki ve kızda tam dokuz; müntehası ikisinde dahi 15 yaştır." (md. 986) diyerek çoğunluğun görüşünü esas almıştır. Ancak Ebû Hanîfe (ö. 150/767), büluğun üst sınırını kızlarda 17, erkeklerde 18 yaşın bitimi olarak kabul etmiştir. Osmanlı Hukuk-ı Aile Kararnamesi de Ebû Hanîfe'nin görüşü doğrultusunda düzenlenmiş ve orada "Ehliyet-i nikâhı haiz olmak için hâtıbın (evlenecek erkek) 18 ve mahtûbenin (evlenecek kız) 17 yaşını itmam etmiş olmaları şarttır." (md. 4) denmiş̧ir (Dağcı, 1996, s. 96; Erbay, 1998, s. 6-7; İbnü'l-Kayyim, 1983, s. 232-233; Üsrûşenî, I, 177-178).

\section{Tarihî Süreçte Çocukta Ceza Ehliyeti}

Çocukluğun yetişkinlikten ayrı bir kategori olarak tanındığı Roma İmparatorluğu'nun ilk büyük kanunlaştırma hareketi olan 12 Levha Kanunları'na kadarki eski Hint, Çin, Mısır, Babil, Etiler gibi uygarlıklarda, çocuk ve suç konusunda yasal düzenlemelerin varlığıyla ilgili bir malumat günümüze ulaşmamıştır. 12 Levha Kanunları'nda ise cezâî sorumluluk, ergenler ve ergen olmayanlar olarak ayrılmaktadır. Babanın, evladın işlediği haksız fiilden dolayı sorumlu tutulduğu ve bu fiilin yaptırımı olarak zararı tazmin etmek, haksız fiil işleyen evladı karşı tarafa vermek, eve hapsetmek, öldürmek gibi yetkilerle donatıldığı bilinmektedir. Kilise'ye itaat düşüncesinin gölgesinde şekillenen Orta Çağ'da çocuk üzerindeki mutlak baba otoritesine eklenen dinsel otorite ve skolastik düşüncedeki çocuğu ilk günahın sonucu gören gelenek, çocuk ve suça ilişkin hukukî düzenlemeleri de etkilemiştir. Artık sadece babaya değil Kilise'ye de tanınan bu yetki, çocuğun cezâî sorumluluk yaşının yediye kadar inmesine neden olmuştur (Centel-Zafer-Çakmut, 2005, s. 361-362; Çeker, 1990, s. 17-19; Ümit, 2006, s. 6-7, 11; Şensoy, 1947, s. 515).

Suç işlemiş çocuğun durumuna ait toplumsal algı, aslında toplumsal tarihin aşamalarına göre değişen çocuk - iktidar ve suç paradigmasına bağlı olarak değişmektedir. Bu aşamalardan ilki, babanın çocuk üzerindeki mutlak otoritesinin kabul edildiği Antik Yunan ve Roma uygarlıklarının hüküm sürdüğü dönem; ikincisi dinsel iktidarın babanın çocuk üzerindeki iktidarına eklendiği Orta Çağ dönemi; üçüncüsü de modern devlet aygıtının ortaya çıkmasıyla başlayan dönem olarak irdelenebilir (Ümit, 2006, s. 7).

Cezâî sorumluluğun tespitinde ergen olma kriterinin esas alınması, tarihî süreçte çocukların cinsiyetine göre bir ayırımı da beraberinde getirmiştir. Kız çocuklarının daha erken ergen olması gerekçesiyle uygulamada kızların 12, erkeklerin ise 14 yaşında 
ergen olduklarının kabul edildiği görülür. Roma Hukuku'nun Klasik Hukuk diye adlandırılan döneminde ise çocuğun konuşabileceği zamana kadar süregelen yaşlarının kesin sorumsuzluk devresi olarak kabul edildiği, ergenliğe yakın olanların cezasında acıma ve şefkatten kaynaklanan ceza indirimine gidildiği, yine bu konudaki kaynaklardan öğrenilebilmektedir (Ümit, 2006, s. 10).

Tarihî süreçte İslâm dünyasındaki düzenlemelere bakıldığında, cezâî ehliyet yaşının ergen olmaya bağlı olarak belirlendiği, kızlara ve erkeklere göre değişen 9- 15- 17 ve 18 yaşlarının farklı İslâm düşünürlerince savunulduğu ve hukukî uygulamayı belirli dönemlerde bu tartışmaların etkilediği görülür. İslâm Hukuku'nda Kilise hukukundan farklı olarak, yaş küçüklüğü bir tür akıl hastalığı olarak değil, ergenliğin, kişisel olgunlaşma için varlığı gereken sebeplerin oluşma anı olarak kabul edildiği için ceza ehliyetine sınır olarak seçildiği görülür (Şensoy, 1947, s. 517; Ümit, 2006, s. 13).

İslâm Hukuku'na göre, ceza ehliyetine sahip olabilmek için kişinin temyiz gücü yanında ergenlik çağına da gelmiş bulunması şart koşulmuştur. Yapmış olduğu davranışın hukukî sonucunu kavrayabilmesi için kişinin en azından temyiz gücüne sahip olması zorunludur. Ancak yedi yaşından itibaren başlayan temyiz gücü, kişinin gerçekleştirdiği davranışların tüm hukukî sonuçlarını kavrayabilmesi için yeterli değildir. Bu sebeple iyi ve kötüyü ayırt edici bu kavrayışın iyice yerleşmesi de şart koşulmuştur. Dolayısıyla İslâm Hukuku'na göre temyiz gücüne sahip ve ergenlik çağına gelmiş çocukların cezâî ehliyetleri vardır. Ancak, gayr-ı mümeyyiz çocuğun ceza ehliyeti yoktur. Mümeyyiz çocuğun ise Allah haklarına yönelik suçlar (had) ve kısas için ceza ehliyeti bulunmamakla birlikte ta'zîri gerektiren suçlarda sınırlı bir ceza ehliyeti bulunmaktadır (Aydın, 2009, s. 172-173). Mesela kasten adam öldüren mümeyyiz çocuğa, hapis veya ıslah evine konulma yaptırımları uygulanabilir (Avcl, 2004, s. 40).

Çağdaşları olan Batılı hukukçulardan farklı olarak İslâm hukukçuları, küçüklerin arasında mümeyyiz - gayri mümeyyiz ayırımı yaparak, iyiyi - kötüyü ayırt edebilen küçükler için yetişkinlere öngörülen ağır cezaların (had) yerine azarlama, öğüt verme, sopa, teşhir gibi cezalardan (ta'zîr) birinin seçimini ve şiddetini hâkimin takdirine bırakarak uygulanmasını öngörmüşlerdir. İslâm Hukuku'nun cezâî sorumluluğu ergen olma esasına göre belirleme ilkesi, 1858 tarihli Ceza Kanunu'na kadar Osmanlı toplumunda benimsenmişti. Bu kanun, 1810 tarihli Fransız Ceza Kanunu'ndan ilhamla, hatta büyük ölçüde bu kanunun tercümesi olarak hazırlanmıştır (Atılgan, 2009, s. 13; Ümit, 2006, s. 13-14).

1810 tarihli Fransız Ceza Kanunu Klasik Kuram'ın etkisiyle çocuklarda ceza sorumluluğunu her olayda "temyiz kudretinin" bulunup bulunmamasına bağlamıştır. Çocukların mutlak sorumsuz olarak kabul edildiği bir yaş sınırına yer vermeyen kanun, 16 yaşını doldurmayıp da suç işlediği sabit olan çocukların, her olayda temyiz kudreti hâkim tarafından araştırılarak, bulunmadığı takdirde beraat ettirilmesini, şartlara göre ıslah tedbirine hükmedilmesini düzenlemiştir. 16 yaşını doldurmayan failin temyiz kudre- 
tini haiz olduğuna hükmeden mahkemenin, cezadan indirim yoluna gitmesi de bu kanunda öngörülmüştür. Çocukların cezalandırılabilmesini temyiz kudretine bağlayan bu kanun, temyiz kudretinin tanımını yapmamıştır. Kavramın tanımını, 1274 (1858) tarihli Osmanlı Ceza Kanunu yapmıştır. Şöyle ki temyiz kudretini, "fiil ve amelinin neticesi bir cürüm olacağını fark ve temyiz" edebilmek olarak tanımlayarak, fiilin suç olduğunu bilmeyi esas kriter olarak almıştır. Osmanlı Kanunnameleri'nde 1810 tarihli Fransız Ceza Kanunu'ndan etkilenerek hazırlanan 1858 (1274) Ceza Kânunnâme-i Hümâyun'una kadar, İslâm Hukuku'nun ergen olmayan çocuğun kesinlikle ceza sorumluluğunun bulunmadığı ilkesi kabul edilirken bu kanunla beraber ergen olma, sorumluluğun tek belirleyicisi olmaktan çıkarılmış ve çocuğun temyiz kudreti yoksa anne babaya teslimi, temyiz kudreti varsa verilecek cezada indirime gidilmesi düzenlenmiştir. Kanunnamelerle düzenlenen durum bu olsa da, Osmanlı́nın hüküm sürdüğü topraklarda Kadı'ya yörenin örf âdetini anlaşmazlıkların çözümünde kullanmak için tanınan takdir yetkisi, her bölgede değişik uygulamalarla karşılaşılmasına neden olabiliyordu. Nitekim Ömer Lütfü Barkan, böyle mahallî bir düzenlemeyi aktarmaktadır: Kanunname-i Kazai Bozok'un "Ahkam-ı Kuttâuttarîk ve Sürrâk" başlıklı faslının 40. maddesine göre "bu nevi fiilleri işleyen oğlancıklar baliğ olmadık olsa, yani 10 yaşından aşağı olsa cürüm alınmaya, lakin tahfif idüp ta'zir ideler yani dövülüp incideler." (Atılgan, 2009, s. 13; Ümit, 2006, s. 13-14; s. 23-24). Osmanlı uygulamasında Fatih Kânunnâmesi, Kanunî Ceza Kânunnâmesi, Sultan İbrahim ve Dördüncü Murat Kânunnâmeleri ve Tanzimat sonrası düzenlenen kanunlarda cezâî mesuliyete müstenit bir esas olarak sadece büluğun nazar-ı itibara alındığı görülür (Şensoy, 1947, s. 524).

Avrupa'dan farklı toplumsal yapıya sahip olan Osmanlı'da özellikle "bireyciliğin" Avrupa'daki gibi etkili olamadığı sosyal ilişkilerde, çocuğun akrabalar ve komşulardan oluşan cemaat içerisinde büyümeye devam ettiği, ayrıca çocuğu günahkâr sayan dinsel kaynaklı Batı düşüncesinden farklı olarak, Osmanlı'da yine kaynağını dinden alan, çocuğun masumiyet ve safığın temsilcisi olduğu anlayışının hâkim olduğu görülür. Osmanlı'daki çocuğa bakışın ve çocukluk algısının temel belirleyicisinin, itaati terbiyeden sayan "Osmanlı terbiyesi" anlayışının olduğu söylenebilir. Çocuğun, bu itaat kültürü ve dinsel inançlarla kuşatılan maneviyatın çok güçlü olduğu bir ortamda yaşadığı görülür. Bütün bunların neticesi olarak Osmanlı'ya dair çalışmalarda, çocuk suçluluğundan veya artan bir suç işleme oranından söz eden belgelere henüz rastlanmazken 1826 ile 1881 arasındaki 55 yılda Fransa'da suç işleme oranının üç kat arttığını ve çocukların işlediği suçlardaki artışın ise dört kat olduğunu, 1881 'de genel suçluluk içinde \% 15 olan çocuk suçluluğunun 1901'de \% 17'ye çıktığı görülmektedir (Ümit, 2006, s. 24-25; Atılgan, 2009, s. 13-15). Mesela Osmanlı'da sokak çocukları diye bir sorundan söz edilemeyişi konusunda bk. Işık (2007, s. 33-35).

Yakın tarihte İslâm Hukuku'nun en önemli dönüm noktasını teşkil eden Mecelle-i Ahkâm-ı Adliye'de çocukla ilgili bölümlere değinmek uygun olur. Her ne kadar bu kanunda çocuğun hukukî statüsü borçlar hukuku bağlamında ele alınmış ise de İslâm 
Hukuku'nun, çocuğun hukukî durum ve tasarruflarına bağlanacak hükümler açısından bakış açısını yansıtmaktadır. Mecelle, çocukla ilgili hükümlere, hacir, ikrah ve şufa konularını kanunlaştırdığı dokuzuncu bölümde yer vermiştir. Genel itibariyle borçlar hukukunun bir parçası olarak tasarruftan men' konusu çerçevesinde mesele ele alınmıştır. Çocukla ilgili olarak tasarrufların durumu açısından söylemek gerekirse, sağîr-i gayr-i mümeyyizin sözlü tasarrufları zat ve asıl itibarıyla menolunur. Yani kavli tasarrufları batıldır. Bu durumdaki hacir, kuvvetli hacirdir. Sağîr-i mümeyyizin sözlü tasarrufları ise lüzum ve nefazdan men'dir. Bu, orta dereceli bir hacri ifade eder. Mesela sağır-i mümeyyizin birine mal satması, buna örnektir (Ali Haydar, 1330, s. III, 3).

Mecelle'de çocuğun durumunu ifade eden en belirgin konulardan biri olan hacir konusunda, çocukluk, yedi hacir sebebinden biri olarak ele alınmıştır. Sığar (çocukluk), ateh ve cünunla birlikte hâkimin kararına gerek kalmaksızın ve marazı mevt ile mukayyet bulunmayan bir şekilde öz itibariyle mahcur olmayı gerektiren bir sebep olarak görülmüştür (md. 957). Çünkü sığar, gayr-i mümeyyizde aklın bulunmadığına, mümeyyizde ise aklın nâkıs olduğuna binaen tasarrufta zarara ihtimallidir. Mümeyyiz için velinin izniyle sırf yararına olanlarla, zarar ve yarar arasında olanları velinin iznine bağlı olarak sahih sayılmıştır (Ali Haydar, 1330, s. III, 24).

Fiilî tasarruflarda hacir cereyan etmez. Nitekim yeni doğan bir çocuk, birinin değerli cam eşyası üzerine yuvarlanarak itlaf etse, çocuğun malından onun tazmin edilmesi gerekir. Bu da göstermektedir ki, çocuk mâlî cezâî yükümlülükle muhataptır. Bu konu, Mecelle'de şu şekilde yer alır: "Mevâdd-ı ânifede zikr olunan mahcûrînin bey' ve şirâ gibi tasarrufât-ı kavliyyeleri muteber olmaz ise de, kendi fiillerinden neşet eden zarar ve ziyânı zâmin olurlar. Meselâ, bir çocuk, gayr-i mümeyyiz olsa bile, birinin malını itlâf ettikde zamân lâzım gelir" (md. 960). Bunun hukuk mantığı açısından izahı şöyle olur: Kavlî tasarrufların sonuçları hariçte mevcut olmayıp ancak, hukukun onlara değer/hüküm vermesiyle var kabul edilirler. Mesela bir satım işleminin varlığını reddetmek ve hükümsüz saymak, eşyanın hakikatini reddetmek gibi fena bir şey sayılmaz. Ancak insan davranışlarından neşet eden fiilî tasarrufların sonuçları, hariçte mevcut bulunduğu için onlara itibar etmemek caiz olmaz. Mesela bir çocuğun, diğer bir kimseyi katletmesi veya malını itlaf etmesi durumunda, bunun yok olduğunu iddia etmek ve hariçteki mevcudiyetini kaldırmak mümkün değildir. Yani itlaf edilmiş bir malı, itlaf edilmemiş sayarak mahcur çocuğu tazminden kurtarmak mümkün olmaz. Böyle bir iddia safsata olur. Nitekim bir sabi, birini katlettiği zaman diyet ödemesi gerekir. Bu katli, keen lem yekün saymak maktulün ölmediğini iddia etmek olur ki bu da hakikati inkârdır. Burada kasıt unsuru aramak da doğru olmaz. Çünkü buradaki hukukî gereklilik (hitâb), teklîfî değil, sebebe bağlı (vaz'î) olduğundan mükellef olma şartı aranmaz. Nitekim uyuyan bir kişi, yuvarlanıp diğerinin malını telef ettiğinde, her ne kadar kastı bulunmasa da tazminle sorumlu olmaktadır. (Ali Haydar, 1330, s. III, 4-5, 29-29). 
İslâm Hukuku'nda hacir hükmünün meşru kılınmasının temel teorisi, hukuka saygı fikri (ta'zîm li-emrillah) yanında Şari'in kullarına şefkat ve merhameti üzerine kurulmuştur. Mesela çocuğa karşı olan şefkat, mahcura raci bir şefkattir. Neticede onun haklarını korumaya yönelik bir tavırdır (Ali Haydar, 1330, s. III, 6). Dolayısıyla çocuk, her ne kadar şahsı itibariyle cezaya mahal olmasa da mâlî bakımdan sorumluluk sahibi sayılmaktadır.

\section{İslâm Hukuku'nda Mâlî ve Cezâî Ehliyet Bakımından Çocukluk Dönemi}

Sözlükte, "yetki, elverişlilik, liyakat, yeterlilik" anlamlarına gelen ehliyet, kişinin dinîhukukî hükümlere muhatap olmaya elverişliliği anlamında bir fıkıh/hukuk terimidir. Ehliyet, kişinin haklardan faydalanmaya, bu hakları kullanmaya ve borçlanmaya elverişliliği demektir. İnsan cenin safhasından itibaren aklî ve bedenî gelişim seyrine paralel olarak bu ehliyeti kazanmakta ve rüşt (fikrî olgunluk) ile bunu tamamlamaktadır. İslâm Hukuku'nda insan hayatı, hukukî kişiliğin başlamasından itibaren ehliyet açısından çeşitli dönemlere ayrılmış, her bir dönem için ayrı hükümler belirlenmiş ve farklı isimlendirmeler yapılmıştır. Bunun sonucu olarak ehliyet, dinî ve hukukî fiil ve işlemin mahiyeti açısından vucûb ve edâ ehliyeti şeklinde; insan hayatı açısından ise cenin, çocukluk, temyiz, büluğ ve rüşt şeklinde devrelere ayrılmıştır (Bardakoğlu, 1994, s. X, 533-534).

Son devir İslâm hukukçularından Mustafa Ahmed ez-Zerka (ö. 1999), ehliyeti, kanun koyucunun (İslâm Hukuku'na göre Şâri') şahısta takdir ettiği ve kişiyi dinî/hukukî hitaba uygun bir mahal kılan vasıf olarak tarif ettikten sonra, ehliyette yer alan temel özelikleri şu şekilde sıralamaktadır: 1) Ehliyet, kişinin bedenî ve aklî gelişimine göre tedrici bir şekilde tekamül eder. 2) Şahsın gelişim aşamalarına bağlı olarak ehliyetin tayini kanun koyucuya (şâri Allah Teala'ya) aittir. 3) İslâm Hukuku'nda ehliyet, dinî bir hükümdür. Yani fıkıh, ehliyeti dinî hitaba muhatap olma aşamaları açısından incelemekle birlikte şahsa terettüp eden bir takım kanunî hak ve sorumlulukları da dikkate almıştır. 4) İnsanın yükümlülüğü, ehliyeti ile sınırlıdır (Uzunpostalcı, 2006, s. 155-156; Zerkâ, 1998, s. II, 783-784).

Ceza ehliyeti terimi, cezaî sorumluluğa ehil olmayı ve ceza ile yükümlü tutulabilmeyi gösteren bir vasfı ifade etmektedir. Bu, kişiye cezanın terettüp edebilmesi ve infazı için gerekli bir vasıftır. Cezaî hükmün uygulanabilmesi için, teklife muhatap olmak şarttır. Pozitif hukuka göre de ceza ehliyeti, cezayı gerektiren fiili işleyen şahsın cezalandııılabilme yeteneği olarak tanımlanmıştır (Çolak, 2011, s. 108-109; Karslı, 2006, s. 42).

Burada kısaca ehliyet türleri ve insan devreleri hakkında bilgi verildikten sonra, bu konu açısından çocuğun cezâî ehliyet açısından durumu incelenecektir. 


\section{Vucûb Ehliyeti}

Kişinin haklara sahip olabilme ve borç altına girebilme salahiyeti olarak ifade edilebilen vucûb ehliyeti, "dinî-hukukî hak ve borçların doğmasına şahsın elverişli olması" şeklinde tanımlanmıştır. İslâm hukukçularına göre, doğumla tam bir hukukî ve gerçek kişilik başlar ve kişi yaşadığı sürece zimmete (yani borç altına girebilme ve başkasını borçlandırabilmeyi sağlayan hukukî vasfa) ve tam vucûb ehliyetine sahip olur. Nitekim TMK'ya göre de "Kişilik, çocuğun sağ olarak tamamıyla doğduğu anda başlar ve ölümle sona erer" (md. 28). Pozitif hukukta, "hukukî kişilik" denen yaşayan her insanın vucûb ehliyetinin bulunduğunun kabul edilmesi, hem kişinin haklarını hem de insan olma vasıf ve onurunu koruyucu bir rol üstlenir (Bardakoğlu, 1994, s. X, 534-535, Çeker, 1990, s. 66-67; Uzunpostalcı, 2006, s. 156-165; Zerkâ, 1998, s. II, 784-785).

Çocuk açısından vucûb ehliyeti, doğum öncesi ve sonrası şeklinde ikiye ayrılmaktadır. İslâm Hukuku'nda anne karnındaki çocuğa (cenin) doğum sonrasında müstakil bir kişilik kazanacak olması göz önünde bulundurularak, teşekkül anından itibaren eksik bir kişilik ve vucûb ehliyeti (nâkıs vucûb ehliyeti) tanınmıştır (Medkûr, 1969, s. 273-277). Nitekim TMK'da da "çocuk hak ehliyetini, sağ doğmak koşuluyla, ana rahmine düştüğü andan başlayarak elde eder" (md. 28) şeklinde bu husus ifade edilmiştir. Ancak, bu sadece doğuma kadar beklendiğinde zayi olabilecek lehindeki bazı hakların saklı tutulmasından ibarettir. Klasik fıkıh literatüründe, cenin için sağ olarak doğduğunda kendiliğinden sahip olacağı miras, vasiyet, vakıf ve nesep şeklinde dört haktan söz edilmektedir. Ceninin bunlardan faydalanabilmesi, bu hakların doğması için ilgili tarafın kabulünün gerekmediği gerekçesine dayandırılmıştır. Çoğunluk fukahaya göre, bir kanunî temsilcinin cenin adına işlem yapmaya ehil olmadığı ileri sürülürken Mâlikî mezhebine göre bir temsilcinin cenin adına hibe kabul edebileceği, Ahmed b. Hanbel'e göre ise cenine bir malın intikali doğum öncesinde işlerlik kazandığı için mesela gerekli şartlar oluştuğu takdirde ceninin yakınlarına bu maldan nafaka ödenmesi gerektiği anlaşılmaktadır (bk. Medkûr, 1969, s. 287-299; Bardakoğlu, 1994, s. X, 534-535).

Kişi, ehliyetinin özünü ve vazgeçilmez alt sınırını ifade eden vucûb ehliyeti, doğumla tam hale gelmektedir. Bu ehliyet devresinde sayılan sınıflar arasında, temyiz çağına ulaşmamış (gayr-i mümeyyiz) küçükler, deliler ve bunaklar yer alır. Literatürde bu konu, çocuk üzerinden izah edilmektedir. Dün ile bugünü, kâr ile zararı ayırt edecek derecede aklî ve bedenî olgunluğa henüz ulaşmamış bulunan gayr-i mümeyyiz çocuk, vucûb ehliyetine sahip olmasının doğal sonucu olarak, bir takım mâlî haklardan faydalanmaya ve mâlî borçlar altına girmeye tam ehil sayılır. Dolayısıyla da satım, kira, miras, vasiyet, hibe gibi akit ve hukukî işlemler sonucu kendisine intikal eden her türlü hakkı kazanabileceği gibi, kendisi adına yapılan hukukî işlemlerden doğan borçlara, akrabalık nafakası, haksız fiilden doğan tazmin, öşür gibi kamu düzenini ve sosyal yardımlaşmayı gerçekleştirmeye yönelik mâlî borçlara muhatap olur. Ayrıca nesep, hidâne (bakım ve himaye), vakıftan faydalanma, uğradığı zararı tazmin ettirme ve yakınlarından nafaka alma gibi 
hakları da elde eder. Ancak, bütün bu işlemlerin, kanunî temsilcisi tarafından yapılacağı açıktır. Ayrıca yukarıda sayılan bir takım borçlara ehil sayılması, üçüncü şahısların haklarını ve kamu düzenini koruma ihtiyacına binaen ve sınırlı bir çerçevede müsaade edilmiş bir durum olarak görülmelidir (Bardakoğlu, 1994, s. X, 534-535, Çeker, 1990, s. 66-67; Uzunpostalcı, 2006, s. 156-165). Temyiz çağına ulaşmamış çocuğun, cezâî ehliyeti bulunmamaktadır. Dolayısıyla doğrudan şahsına yönelik suç ve ceza sorumluluğundan beridir. Ancak, vucûb ehliyetinin varlığı, mağdurun hakkının korunması amacıyla, haksız fiilden doğan mâlî borçların tazmininde yeterli görülmüştür.

\section{Eda Ehliyeti}

Vucûb ehliyetinin daha kapsamlı hale gelmiş ikinci safhası sayılabilecek olan eda ehliyeti, kişinin dinen ve hukuken muteber olacak tarzda davranmaya ve hukukî işlem yapmaya elverişliliği olarak tanımlanır. Şâri' veya hukuk düzeni, aklî ve bedenî gelişimine paralel olarak kişiye giderek hakları bizzat kullanma yahut bizzat kendi işlemiyle borç altına girebilme yönünde ilave haklar tanır. Eda ehliyeti akıl ve temyiz gücüne dayanır ve çocuğun iyiyi kötüden, faydalıyı zararlıdan ana hatlarıyla ayırabilmesi demek olan temyizle başlar. Temyiz öncesi dönemde bulunmayan eda ehliyeti, çocukta temyiz, büluğ ve rüşt şeklinde ifade edilen üç kademede gerçekleşir. Kârı zarardan ayırabilecek yaşa ulaşmış bulunan mümeyyiz çocukta, aklî gelişimini henüz tamamlamadığı için eksik (nâkıs) eda ehliyeti bulunur. İslâm Hukuku'nda objektif bir ölçü getirmek amacıyla, çocuğun yedi yaşında temyiz gücü kazandığı görüşü hâkimdir (Bardakoğlu, 1994, X, 534-535; Çeker, 1990, s. 66-67; Uzunpostalcı, 2006, s. 156-165; Zerkâ, 1998, II, 784-785).

İslâm hukuk ilminde mümeyyiz çocuğun eda ehliyeti, dinî ve hukukî (medenî) şeklinde iki kısımda incelenir. Dinî eda ehliyeti, çocuğun yapmış olduğu ibadetlerin geçerliliği açısından ele alınır. Hanefî mezhebine göre, mümeyyiz çocuğun hukukî işlem yapabilme yetkisini ifade eden hukukî (medenî) eda ehliyetine dayalı olarak gerçekleştirdiği mâlî işlemler, sırf faydasına ve mal varlığının artışına yol açanlar geçerli; hem kâr hem zarar yönü bulunan ivazlı akitler, ancak, kanunî temsilcisinin izin veya onayı ile geçerli; sırf zararına ve mal varlığının azalmasına sebep olan işlemler ise kendisi veya kanunî temsilcisinin onay hakkı bulunmadığı için geçersizdir. Mâlikiler de yaklaşık olarak Hanefîlerle aynı kanaati paylaşmaktadırlar. Şafii ve Zahirilere göre ise bazı istisnai durumlar haricinde kural olarak büluğ öncesi çocuğun hukukî işlem yapmaya ehliyeti bulunmamaktadır. Hanbeliler ise sırf menfaatine olan durumlarda da veli iznini şart koşmakta, kâr ve zarar yönü bulunan işlemlerde veli onayını yeterli görmemekle birlikte, aleyhine bir işlem olduğu halde boşama ve bu konuda vekâlet vermesini caiz görmektedirler (Bardakoğlu, 1994, s. X, 535).

Çocuğun tam eda ehliyetini büluğ ile mi yoksa rüşt ile mi elde edeceği tartışmalı olmakla birlikte, çoğunluk İslâm hukukçuları, mâlî yönü bulunan hukukî işlemlerde tam eda ehliyetinin aklî olgunluğu gösteren rüşt ile kazanılacağı görüşündedirler. Tam eda 
ehliyetine sahip olan kişi, artık cezâî sorumluluklar dâhil bütün tasarruflara ehil hale gelmiş bulunmaktadır. Tam eda ehliyeti için tabii büluğun esas alınmayıp belli bir yaş sınırlaması getirildiği, birçok kanunlaştırmada görülmektedir. Nitekim Tanzimat'tan sonra hazırlanan Emvâl-i Eytâm Nizamnamesi yetimlerin rüşt yaşı olarak yirmi yaşı belirlemiş; ancak, bu yaşa ulaştığında mallarının teslim edileceği esasını getirmiştir. Yukarıda değinildiği üzere Mecelle'de büluğ yaşının sonu konusunda on beş yaş ölçü alınmışken (md. 986), 1917 tarihli Hukûk-ı Âile Kararnâmesi'nde evlenme ehliyeti için Ebû Hanîfe'nin görüşüne uyularak erkeklerin on sekiz, kızların on yedi yaşını bitirmiş olmaları şartı getirilmiştir (md. 4). Kararnamede, bu yaşa ulaşmamış kızlar için velisinin izni aranmış (md. 6), kızların dokuz, erkeklerin ise on iki yaşından önce evlendirilemeyeceği hükme bağlanarak (md. 7) evlenme ehliyeti için alt sınır getirilmiştir (Bardakoğlu, 1994, s. X, 538; Bu kararların esbâb-ı mucibe lâhikası için bk. Çeker, 1999, s. 78-79).

Küçük çocukta olduğu gibi mümeyyiz çocukta da haksı fiillerinden dolayı tazmin sorumluluğu vardır. Çünkü haksız fiillerde, kusur sorumluluğu aranmamaktadır. Dolayısıyla burada failin kasıt veya kusurunun bulunması değil, vucûb ehliyetine sahip olması esastır. Nitekim Mecelle'de "Mübaşir müteammid (kasıtlı) olmasa da zâmin (tazminle sorumlu) olur" (md. 92) denmiştir. Eda ehliyetinde ise failin, dinen ve hukuken geçerli bir kasıt ve iradesinin bulunması gerekir. Neticede suç unsurunun oluşması ve cezâi sorumluluğun gerçekleşmesi, tam eda ehliyetinin varlığına bağlıdır (Bardakoğlu, 1994, s. X, 538). Yukarıda geçen yaş sınırındaki ihtilafla birlikte, rüşt çağına ulaşan kişinin, tam eda ehliyeti bulunduğu için tam ceza ehliyeti de var sayılır ve işlediği tüm fillerden tamamen sorumludur. Her ne kadar ceza ehliyetine sahip olabilmek için reşit olmak şart değilse de reşit kişi, zaten eda ehliyetine sahip bulunduğu için çocukluktan çıkmış, tam ve yetişkin bir birey haline gelmiş bulunmaktadır.

İslâm hukukçuları, bir fiilin suç olarak değerlendirilebilmesi ve failine cezâî müeyyide uygulanabilmesi için bu fiili işleyenin, âkil ve baliğ olmasını şart koşmuşlardır. Bu açıdan onlar, ceza ehliyetini suçun oluşmasında manevi unsur olarak değerlendirmiş olmaktadırlar. (Dağcı, 1996, s. 20). Nitekim âkil olmayan çocuklar ve akıl hastaları ya da âkil olup henüz büluğa ermemiş çocuklar, ağır cezayı (had ve kısas) gerektirecek suç işleseler, kendilerine ilgili cezalar uygulanmaz. Çocuğun bedenî cezalara ehil olmadığı, şu hadis-i şeriflere dayanmaktadır: "Çocuk on beş yaşını tamamladığı zaman kendisine ağır cezalar (hadler) uygulanır" (Beyhakî, Sünen, s. VI, 57). "Üç kişiden sorumluluk kaldırılmıştır: Uyanıncaya kadar uyuyan kimseden, büluğa erinceye kadar çocuktan, aklî dengesine kavuşuncaya kadar akıl hastasından" (Ebû Dâvûd, "Hudûd",17). Çocukların işledikleri suçlardaki kasıtları muteber olmadığı için hata olarak kabul edilir. Bu sebeple, mesela murisini öldüren çocuk mirastan mahrum olmaz (Çeker, 1990, s. 209-210; Üsrûşenî, s. I, 193-198). Nitekim Osmanlı döneminde ait bir fetvayı örnek vermek gerekirse, Ali Efendi'nin Fetâvâ'sında (s. 171) hırsızlık haddinin çocuğa uygulanmayacağını gösteren bir ibare, şu şekilde yer alır: "Zeyd-i sağîr, menzilinde olan mekân-ı muhrezinden kıymet- 
leri nisâb-ı serikaya bâliğ şu kadar eşyasını hufyeten ahz eylese şer'an kat-ı yed lazım olur mu? el-Cevap: olmaz." (Avcı, 2004, s. 241).

Takdiri hâkimin yetkisine bırakılmış olan cezalara (ta'zir) ehil olmak için ise âkil olmak yeterli görülmüştür. Ancak, ta'zir cezaları, işledikleri fiiller gerçek anlamda suç sayılamayacağı için, mecazen suç addedilerek, çocuğun tedip ve terbiyesi kastıyla uygulanır. Yani bu, çocuğu kötü fiilden alıkoyucu zecrî bir tedbir olup buna günümüz ceza hukukunda "tedbir sorumluluğu" denir. Günümüz ceza hukukunda, "güvenlik tedbiri" ifadesi kullanılmaktadır (TCK, md. 56-58). Dolayısıyla âkil çocukta, ceza sorumluluk ehliyeti değil de zecrî tedbir ehliyeti bulunmaktadır. Ancak, bu zecrî tedbirler, âkil olmayan çocuklara uygulanmamaktadır (Çeker, 1990, s. 210-211).

Çocuğun devreleri açısından meseleye bakıldığında, gayr-i mümeyyiz küçüğün hiçbir cezâi sorumluluğu olmadığı görülür. Ancak, buna mukabil mümeyyiz küçüklere tedip mahiyetinde ta'zir tatbik edilmesi, onları gayr-i mümeyyizlerden ayırmaktadır (Erbay, 1998, s. 80-81). Çocuğun cezâî sorumluluğunun olmaması, mâlî sorumluluğunu engellememektedir. Yukarıda da ifade edildiği üzere, üçüncü şahısların ve mağdurların haklarının korunması amacıyla çocuğun, başkasının malına vermiş olduğu zarardan dolayı tazmin sorumluluğu var kabul edilir. Nitekim küçüklük ve kısıtılık, mâlî sorumluluğa engel değildir. Mecelle'de bu husus, şu şekilde ifade edilmiştir: "Bir sabî, diğerin malını itlaf etse kendi malından zaman (tazmin) lazım gelir; malı yoksa hal-i yüsrüne (malı bulunacağı zenginlik zamanına) intizar olunur (beklenir); velisine tazmin ettirilmez" (md. 916) (Çeker, 1990, s. 209-214; Ûdeh, 1987, I, 602-604). Cezâî sorumlulukta failin kusur derecesinin, yani kasıt, ihmal veya taksirinin, suçu işleme durum ve aletinin farklı sonuçları vardır. Yaş küçüklüğü gibi eda ehliyetine tesir eden haller mâlî sorumluluğu pek etkilemezse de cezâî sorumluluğa değişik derecelerde müessir olur (Bardakoğlu, 1993, VII, 476). Hakların heder olmaması için, "Şer'î özürler, dokunulmazlıkları ortadan kaldırmaz." prensibi gereğince çocuk, medenî yönden sorumlu tutulmakta ve suça öngörülen mâlî cezalar kanunî temsilcilerine tazmin ettirilmektedir. Yani çocukların fiillerindeki kasıt, hükmen taksir kabul edilmektedir (Avcı, 2004, s. 125; Dağcı, 1996, s. 96).

Bu noktada İslâm ülkelerinden bir uygulama örneği olarak Mısır'daki duruma işaret etmek uygun olur. Mısır'da İslâm Hukuku'nun klasik görüşü esas alınarak, küçüklerle ilgili olarak 1974 yılında yürürlüğe giren 31 sayılı kanunun 7. Maddesinde, küçüklerin 15 yaşına kadar cezâî ehliyetlerinin olmadığı kabul edilmiştir. Bu dönemde küçüklerin, suç sayılacak bir fiil işlemeleri halinde tedip mahiyetinde kınanacağı, bir aileye, belli bir alanda beceri kazanmasını sağlayacak bir iş merkezine veyahut da eğitim ve gözetimi için özel ya da resmî kuruluşlara yerleştirilebileceği karara bağlanmıştır. Yine aynı kanunun 15. maddesinde ise 15 yaşına girmiş; fakat 18 yaşını henüz doldurmamış olan kişinin nâkıs ceza ehliyetine sahip olacağı, bu devrede hâkimin 7. maddede sayılan tedbirlerin yanında ceza uygulama cihetine de gidebileceği, ancak buna lüzum görmemesi halinde tedbir uygulaması ile yetinebileceği kayıt altına alınmıştır (Erbay, 1998, s. 83). 


\section{Günümüz Türk Hukukunda Ehliyetin Kısımları}

Günümüz pozitif hukuk sisteminde ehliyet bahsi, özel hukukun alt bölümü olan Medenî hukukun altında "kişiler hukuku" kısmında yer almaktadır. Burada kişi, haklara sahip olma ve borçlarla yükümlü olma bakımından incelenmektedir. Ayrıca kamu hukukunun altında yer alan ceza hukuku bölümünde, kişinin cezaya ehil olması bakımından durumu incelenmektedir. Burada ise ceza ehliyeti üzerinde durulmaktadır (Bilge, 2003, s. 114, 148-149).

\section{Hak Ehliyeti (Medenî Haklardan Istifade Ehliyeti)}

Hak ehliyeti, hak sahibi olabilme ehliyeti demektir. Bu medenî haklardan istifade ehliyetinde kişi (şahıs) pasif durumda olup herhangi bir fiil ve harekette bulunmadan, kendisinin irade beyanına ihtiyaç duyulmadan bu ehliyete konu olan hakları kendiliğinden kazanır. Ancak, hakkı kazanma, şahsın bütün haklardan istifade etmesi anlamında değil, haklardan istifade etmeye ehil olması anlamındadır. Nitekim bir şeyden istifade etmeye ehil olmak ile ondan fiilen istifade etmek farklı şeylerdir. Mesela bir kimse mal sahibi olmaya ehil olur; ancak fiilen mala sahip olamayabilir. Dolayısıyla herkes medenî haklardan istifade etmeye ehildir ve bu konuda herkes eşittir (Bilge, 2003, s. 114; Uzunpostalcı, 2006, s. 151). Türk Medenî Kanunu'nda (TMK) konuyla ilgili olarak şöyle denmektedir: "Her insanın hak ehliyeti vardır. Buna göre bütün insanlar, hukuk düzeninin sınırları içinde, haklara ve borçlara ehil olmada eşittirler." (md. 8)

Medenî haklardan istifade etmeye ehil olabilmek için ileride insan olarak sağ doğmak şartıyla anne karnında cenin olmak yeterlidir. Nitekim TMK'da: "Kişilik, çocuğun sağ olarak tamamıyla doğduğu anda başlar ve ölümle sona erer. Çocuk hak ehliyetini, sağ doğmak koşuluyla, ana rahmine düştüğü andan başlayarak elde eder." (md. 28) denmektedir.

\section{Fiil Ehliyeti (Medenî Hakları Kullanma Ehliyeti)}

Fiil ehliyeti, kişinin fiil ve hareketleriyle, yaptığı işlemlerle hak meydana getirebilmesi, alacaklı veya borçlu durumuna gelebilmesi salahiyeti demektir. Kişinin bu ehliyete sahip olabilmesi için birtakım bedenî ve fıtri olgunluğa ulaşması gerekmektedir. Nitekim yeni doğan bir çocuk, medenî haklardan istifade etme ehliyetine sahip olduğu halde gerek bedenî gerek fıtri kabiliyeti itibariyle zayıf ve hakları kullanamayacak durumda olduğu için fiil ehliyetine sahip değildir. Medenî hakları kullanma ehliyeti, çocuğun büyümesi ve çeşitli dönemler geçirmesiyle gelişecektir. Medenî kanunda konu ile ilgili olarak şöyle denmektedir: "Fiil ehliyetine sahip olan kimse, kendi fiilleriyle hak edinebilir ve borç altına girebilir (md. 9). Ayırt etme gücüne sahip ve kısıtlı olmayan her ergin kişinin fiil ehliyeti vardır (md. 10). Erginlik onsekiz yaşın doldurulmasıyla başlar (md. 11)."

Medenî hukuka göre, fiil ehliyeti açısından insanları, daha doğrusu insanın geçirdiği devreleri gruplara ayırmak gerekir. Bu grupları ve bunlar içerisinde bulunan insan- 
ların salahiyet durumlarını şu şekilde açıklamak mümkündür: (Bilge, 2003, s. 114; Uzunpostalcı, 2006, s. 152-153).

\section{Tam Ehliyetliler}

Tam ehliyetli, hukuken bütün haklarını kullanmaya ehil olup kendisinde haklarını kullanmayı sınırlayıc bir durum bulunmayan kimsedir. Bu kişi, reşit (medenî kanuna göre on sekiz yaşını doldurmuş) ve mümeyyiz olmalı, mahcur (kanunî temsilciye ihtiyaç duyan) olmamalıdır.

\section{Mahdut Ehliyetliler}

Kendilerinde ehliyetli olma asıl olduğu halde, kanunun kendilerini korumak maksadıyla bazı hukukî muamelelerde tam ehliyetli görmediği kişilerdir.

\section{Tam Ehliyetsizler (Fiil Ehliyetsizliği)}

Bu sınıfta yer alanlar; küçükler, mümeyyiz olmayanlar ve reşit olup da kısıtlı (mahcur) olanlardır. Nitekim bu konu TMK'da şöyle ifade edilmiştir: "Ayırt etme gücü bulunmayanların, küçüklerin ve kıııtıların fiil ehliyeti yoktur. Kanunda gösterilen ayrık durumlar saklı kalmak üzere, ayırt etme gücü bulunmayan kimsenin fiilleri hukukî sonuç doğurmaz." (md. 14-15). Ayırt etme gücü (temyiz) ise medenî kanunda şöyle tarif edilmiştir: "Yaşının küçüklüğü yüzünden veya akıl hastalığı, akıl zayıflığı, sarhoşluk ya da bunlara benzer sebeplerden biriyle akla uygun biçimde davranma yeteneğinden yoksun olmayan herkes, bu kanuna göre ayırt etme gücüne sahiptir." (md. 13).

\section{Mahdut Ehliyetsizler}

Çocuklar, reşid olmamış mümeyyizler, mahcur mümeyyizler sırf lehlerine olan haklara ve haksız fiillerinden doğan borçlanmalara ehildirler. Ancak fiil ehliyeti açısından ehliyetsiz olma bunlar için asıldır.

Bu hususlar Medenî Kanunda: "Ayırt etme gücüne sahip küçükler ve kısıtlılar, yasal temsilcilerinin rızası olmadıkça, kendi işlemleriyle borç altına giremezler. Karşılıksız kazanmada ve kişiye sıkı sıkıya bağlı hakları kullanmada bu rıza gerekli değildir. Ayırt etme gücüne sahip küçükler ve kısıtılar haksız fiillerinden sorumludurlar." (md. 16) şeklinde ifade edilmektedir. Şunu da ifade etmek gerekir ki bu haklar kişiye insan olmasının gereği verilmiştir ve hiçbir şekilde bunları reddedemez, devredemez, hukuka ve ahlaka aykırı olarak kullanamaz. Bu husus TMK'da: "Kimse, hak ve fiil ehliyetlerinden kısmen de olsa vazgeçemez. Kimse özgürlüklerinden vazgeçemez veya onları hukuka ya da ahlâka aykırı olarak sınırlayamaz." (md. 23) şeklinde ifadesini bulmuştur (Tiryakioğlu, 1991, s. 11-13).

Türk Ceza Kanunu'nda çocuk henüz 18 yaşını doldurmamış kişi olarak tanımlanmaktadır. Cezâî ehliyet açısından ise 12 - 15 - 18 yaşlarını doldurup doldurmamış olmalarına göre çocukların durumu değişiklik arz etmektedir. Daha önceleri 11 olan ceza sorumluluğu (hakkında kovuşturma yapılabilmesi) yaşı 2004 yılında 12'ye çıkarılmıştır (Avcı, 2005, s. 369-370). 


\section{TCK'da Cezâî Sorumluluk Ehliyeti Bakımından Evreler (md. 31)}

\section{0-12 yaş arası tam sorumsuzluk hali}

Bu devrede yer alan çocukların herhangi bir cezâî sorumluluğu bulunmamaktadır. Bu durum TCK'da şöyle ifade edilmektedir: "Fiili işlediği sırada oniki yaşını doldurmamış olan çocukların ceza sorumluluğu yoktur. Bu kişiler hakkında, ceza kovuşturması yapılamaz; ancak, çocuklara özgü güvenlik tedbirleri uygulanabilir." [TCK, md. 31 (1)\}.

\section{3-15 yaş arası tam sorumsuzluk veya sınırlı sorumluluk hali: [md. 31 (2)].}

\section{3-15 yaş arası tam sorumsuzluk hali}

Fiili işlediği sırada oniki yaşını doldurmuş olup da onbeş yaşını doldurmamış olanların işlediği fiilin hukukî anlam ve sonuçlarını algılayamaması veya davranışlarını yönlendirme yeteneğinin yeterince gelişmemiş olması halinde ceza sorumluluğu yoktur. Ancak, bu kişiler hakkında çocuklara özgü güvenlik tedbirlerine hükmolunur.

\section{3-15 yaş arası sınırlı sorumluluk hali}

İşlediği fiili algılama ve bu fiille ilgili olarak davranışlarını yönlendirme yeteneğine sahip çocuklar: Bu kişiler hakkında suç, ağırlaştırılmış müebbet hapis cezasını gerektirdiği takdirde on iki yıldan on beş yıla; müebbet hapis cezasını gerektirdiği takdirde dokuz yıldan onbir yıla kadar hapis cezasına hükmolunur. Diğer cezaların yarısı indirilir ve bu halde her fiil için verilecek hapis cezası yedi yıldan fazla olamaz.

\section{6-18 yaş arası sınırlı sorumluluk hali}

Fiili işlediği sırada 16-18 yaşları arasında olan kişilerde temyiz yeteneği var kabul edilmektedir. İtiraz durumunda bilirkişi incelemesi isteyebilirler. Bunlar işledikleri suçlardan dolayı sorumludurlar. Ancak bunlara fiilin yaptırımı indirimli uygulanmaktadır.

Önceden kullanılan "farik ve mümeyyiz" kavramları yerine yeni kanunda "işlediği fiilin hukukî anlam ve sonuçlarını algılama ve bu fiille ilgili olarak davranışlarını yönlendirme yeteneğine sahip olma" kavramları getirilmiştir. Ancak, maddenin düzenlemesine göre bu iki yetenek birlikte bulunduğu takdirde 13-15 yaş arasındaki kişilerin sınırlı sorumluluk hali var kabul edilmektedir. Yukarıda geçen Medenî Kanun'daki ayırt etme gücü tanımlanırken kişideki manevi güce olumsuz etki eden durumlar açısından değerlendirilmekte, dolayısıyla bu olumsuz durumların yokluğu kişinin ayırt etme gücüne sahipliğini göstermektedir. Buna göre ayırt etme gücü'nün varlığı durumunda "haksız fiillerinden sorumludurlar"; dolayısıyla işledikleri suç fiillerinden de sorumludurlar (Bilgi ve değerlendirme için bk. Şafak, 2005, s. 327-329). Ceza ehliyetinde temeli, "isnat yeteneği" kavramı yani fiilin sosyal değerini kavrayabilmek ve buna göre davranışlarını yönlendirebilmek yeteneği oluşturmaktadır (Ümit, 2006, s. 2). Nitekim isnat yeteneği kavramı, bir fiilin bir kimsenin üstüne atılabilmesi, ona yüklenebilmesi için, failde bulunması gereken niteliklerin bütününü ifade etmektedir (Artuk-Gökcen-Yenidünya, 
2002, s. I, 538-544; Artuk-Gökcen-Yenidünya, 2002, s. I, 544-554; Centel-Zafer-Çakmut, 2005, s. 362-372; Dönmezer-Erman, 1999, s. II, 145; ayrıca Türk Ceza Hukuku açısından çocuklara ilişkin dönemler hakkında bk: Demirbaş, 2006, s. 316-322).

\section{Çocuk Suçluluğu ve Çocuk İstismarı Açısından Ceza Ehliyeti}

Gerek uluslararası hukuk, gerekse millî hukukta çocuk suçluluğu ile ilgili mevzuat çalışmaları yapılmıştır. Hatta bu konu, uluslararası sözleşmelerde yer almıştır. Çocuk suçluluğu konusundaki mevzuatın arka planında genel itibariyle suça sürüklenen çocukların erişkinler tarafından kullanıldığı ön kabulü etkilidir. Çocuk suçluluğu ile ilgili mevzuat, çocuk suçluluğunu önleme amaçlı olanlar; suça sürüklenmiş sanık çocukların yargılanması ile ilgili kurallar ve mahkemeler; mahkum olanlara hükmedilen yaptırımların infazına ilişkin olanlar şeklinde sınıflandırılabilir (Avcı, 2005, s. 356). Uluslararası hukuk metinlerine paralel olarak Türkiye'de de suç hukuku bakımından sanık çocuğun yaşı, hem cezâî sorumluluk hem de yargılama hukuku alanlarında uygulanacak kurallar açısından 18'e çekilmiştir (Şafak, 2005, s. 327).

Suç işleme fırsatını artıran şartlar oluştukça, toplumsal algıdaki "suçlu çocuk" imajının da güçlendiği görülür. Yine ters bir orantı ile toplumdaki "suçlu çocuk" imajından kaynaklanan damgalamanın, suç işleme fırsatını artıran şartlar arasında sayılması mümkündür. Dolayısıyla damgalamanın, çocukların kendilerine bakışları ve davranışları üzerinde etkili olduğu söylenebilir. Çocukların yaşadıkları ortam, fiziksel, toplumsal, zihinsel süreçler ağı olarak düşünüldüğünde bu ortamın çocuk suçluluğu üzerindeki etkisi göz ardı edilemeyecek kadar önemlidir (Ümit, 2006, s. 3).

Şu anki Çocuk Koruma Kanunu'nda (5395) "suçlu çocuk" yerine "suça sürüklenen çocuk" ifadesi kullanılmaktadır. Suça sürüklenen çocuk terimi, kanunlarda suç olarak tanımlanan bir fiili işlediği iddiası ile hakkında soruşturma veya kovuşturma yapılan ya da işlediği fiilden dolayı hakkında güvenlik tedbirine karar verilen çocuğu ifade eder. (ÇKK, md. 3/2). Çocuk Koruma Kanunu, çocuğun haklarını koruma altına alan hükümler ile çocuğun öncelikle kendi aile ortamında korunmasını sağlamaya yönelik tedbirleri içeren ve de suça sürüklenen ve ceza sorumluluğu olmayan çocuklara özgü güvenlik tedbirlerini de ihtiva eden elli maddelik bir hukukî düzenlemedir.

Bir diğer önemli husus ise çocukları suç işlemeye meyilli hale getiren ve onları suça iten sebeplerdir. Bunların başında; aile içi şiddet, yanlış arkadaş seçimi, ailede geçimsizlik, şaşaalı hayatlara duyulan özenti, erken yaşlarda çalışmak zorunda kalma, yetiştirme yurtlarının yetersizlikleri, kolay para kazanma arzusu, çocuklar üzerindeki kontrolün zayıflaması, yardımlaşma olgusunun zayıflaması, gecekondu bölgelerindeki zor yaşam koşulları, sevgi, ilgi ve anlayış eksikliği, gelir dağılımındaki adaletsizlikler, çeteler, organize örgütler ve işsizlik gelir (Işık, 2007, s. 75-76). 
Çocuk istismarı, 18 yaşın altındaki çocuklara karşı aktif olarak girişilen ve onların fiziksel, duygusal, zihinsel ve toplumsal gelişimlerini zedeleyen her türlü eylemi ifade eder. Bu meyanda kullanılan diğer bir terim olan çocuk inmali ise, çocukların beslenme, bakım, gözetim, eğitim gibi gereksinimlerinin karşılanmamasıdır (Çiğdem, 2005, s. 184). Çocukların istismarı ve ihmali, fiziksel, psikolojik, cinsel ve ekonomik olmak üzere dört ana konuda toplanabilir. Ayrıca istismara neden olan unsurlar açısından ise anne-baba tarafından kötü muameleye maruz kalma, anne-baba yoksunluğu, ölüm, boşanma veya ayrı yerlerde çalışma gibi nedenlerle parçalanmış ailede yaşama gibi aileden kaynaklanan istismar ve inmaller; eğitim kurumlarında ve bakım ve tedavi merkezlerinde yetkililer ya da bizatihi arkadaşları tarafından uğradıkları haksızlıklarda olduğu gibi kamudan kaynaklanan istismar ve ihmaller; potansiyel ucuz iş gücü olarak görülmeleri nedeniyle gerek aileleri gerekse sokağa düşmüş olanların çeteler ve büyükleri tarafından ekonomik olarak istismarı (çocuğun çalışması, gelirinin korunması ve istismarının önlenmesi konusunda İslâm hukukçularının yaklaşımları hakkında bk. Köse, 2005, s. 117-159); haberlerde, filmlerde ve hatta çizgi filmlerde şiddet ve cinsellik içerikli yayınların sıkça yer alması, pornografik yayınların yaygınlaşması gibi basın yayın kaynaklı istismarlar sayılabilir (Çiğdem, 2005, s. 187-192).

Burada cezâî ehliyetin istismarı açısından meseleye bakıldığında, iki husus zikredilebilir. Birincisi; Doğu ve Güneydoğu Anadolu bölgelerinde kız çocuklarının maruz kaldıkları durumdur. Bu çocuklar töre cinayetleri tabir edilen bir şiddetle karşı karşıya kalmaktadır. Bu noktada, önceleri cezâi ehliyetin bulunmaması istismar edilerek bu tür cinayetler için küçükler (genellikle maktulün kardeşi) kullanılmaktaydı (örnek için bk. Çiğdem, 2005, s. 188-189). Türk Ceza Kanunu'nda seksen yıldır cari olan uygulama, aile içi namus cinayeti olarak bilinen ve genelde ölümle sonuçlanan cinayetlerde mağdurların yaşadığı hukuk dışı cinsel ilişkide bulunma girişimleri, öldürme suçunun faillerince haksız tahrik sayılmakta ve cezasında indirim yapılmaktaydı. 2004 yılında kabul edilen yeni TCK'da "Üstsoy ve altsoy ilişkisinden doğan nüfuz kullanılmak suretiyle suça azmettirme hâlinde, azmettirenin cezası üçte birden yarısına kadar artırılır. Çocukların suça azmettirilmesi hâlinde, bu fıkra hükmüne göre cezanın artırılabilmesi için üstsoy ve altsoy ilişkisinin varlığı aranmaz." (md. 38/2) hükmü getirilerek bu yeni düzenlemeyle töre cinayetlerine son verilmek istenmiştir. Yine bir özel suç durumu "fuhuş" konusunda da istismarı önleyici düzenleme getirilmiştir. TCK'da "Çocuğu fuhşa teşvik eden, bunun yolunu kolaylaştıran, bu maksatla tedarik eden veya barındıran ya da çocuğun fuhşuna aracılık eden kişi, dört yıldan on yıla kadar hapis ve beş bin güne kadar adlî para cezası ile cezalandırılır. Bu suçun işlenişine yönelik hazırlık hareketleri de tamamlanmış suç gibi cezalandırılır... ...Yukarıdaki fıkralarda tanımlanan suçların eş, üstsoy, kayın üstsoy, kardeş, evlat edinen, vasi, eğitici, öğretici, bakıcı, koruma ve gözetim yükümlülüğü bulunan diğer kişiler tarafından ya da kamu görevi veya hizmet ilişkisinin sağladığı nüfuz kötüye kullanılmak suretiyle işlenmesi hâlinde, verilecek ceza yarı oranında artırılır." (md. $227 / 1,5)$ denmektedir. Bu düzenlemeler ile özellikle çocukların aile ve kamu kurumlarında cinsel istismarının önüne geçilmek istenmiştir (Şafak, 2005, s. 327-333). 
İkinci örnek ise büyük şehirlerde kentleşmenin getirdiği bir problem olarak sokak çocuklarının dilencilik, hırsızlık ve kapkaç gibi suçlara alıştıııması, hatta zorlanması şeklinde ortaya çıkan, çocukların organize suçlarda istismarı konusudur. Esas itibariyle burada istismar edilmek istenen husus, çocukların ceza ehliyetlerinin yokluğudur. Burada çözüm, çocukların cezaya ehil sayılıp yetişkinlerin benzeri bir cezaya çarptırılmaları değil, onların bu ortamlara itilme sebeplerinin ortaya çıkarılması ve buralardan kurtarılmalarını sağlayacak önlemlerin alınması için çalışmalar yapılmasıdır. Bu konuda yapılan en son düzenleme ile çocukların, suç örgütlerinin istismarına itilmesinin önlenmesi amacıyla Terörle Mücadele Kanunu ve diğer bazı kanunlarda, "Bu madde hükümleri çocuklar hakkında uygulanmaz." denilerek çocuklar lehinde bazı değişikliklere gidilerek 22/7/2010 tarihinde özel bir kanun çıkarılmıştır (Kanun No: 6008).

Bir diğer olumlu gelişme de 12 Eylül 2010 tarihinde referandum sonucu kabul edilen anayasa değişiklikleri içerisinde çocukları her türlü istismar ve şiddete karşı daha fazla korumak amacıyla çocuk hakları ile ilgili bir maddenin de yer almasıdır. Anayasanın 41. Maddesi'ndeki ilave düzenleme şu şekildedir: "Her çocuk, korunma ve bakımdan yararlanma, yüksek yararına açıkça aykırı olmadıkça, ana ve babasıyla kişisel ve doğrudan ilişki kurma ve sürdürme hakkına sahiptir. Devlet, her türlü istismara ve şiddete karşı çocukları koruyucu tedbirleri alır." Bu değişiklik de çocuk hakları konusunda demokratik açıdan oldukça sevindirici bir aşama olarak görülmelidir.

Çocuk hakları konusu; oldukça geniş, birçok alanı ilgilendiren, henüz tam olarak literatürü tamamlanmamış, derinlemesine araştırmalara ihtiyaç duyan bir konudur. Çocukla ilgili problemlerin, sadece bir açıdan alınan tedbirlerle çözülmesini beklemek mümkün değildir. Nitekim sırf ceza hukuku sisteminde radikal değişiklikler yapılmasının, pratik hayat açısından yeterli olmayacağı anlaşılmaktadır (Adams, 1993, s. 140).

Başarılı sosyalleşme, suçu önleyici önemli bir unsurdur. Çocuk suçluluğunun önlenmesinde, çocukların topluma uyum sağlamaları ve sosyalleşmelerinin önemi büyüktür. Bir başka ifadeyle sosyal uyumsuzluk, suç için gerekli ortamın oluşmasını sağlamaktadır. Dolayısıyla bir toplumda uyum ne kadar iyi olursa, suç oranı da o kadar düşük olmaktadır. Toplum üyelerinin uyum içinde yaşamalarında dinin etkisi ise güçlüdür. Din, kardeşliğe ve hakları gözetmeye çağırarak uyumun egemen olduğu bir toplum inşa etmeyi arzulamaktadır. Dolayısıyla din, çocuğun sosyalleşmesinde olumlu etki sahibidir. Nitekim Hz. Peygamber'in çocuklarla ilişki biçimi ve de İslâm toplumunda çocuğa davranış modeli, çocuğun sosyalleşmesinde etkili bir model olmuştur (Okumuş, 2005, s. 403-406). Nitekim temelde kanunlara ve topluma saygılı ve uyumlu bireylerin yetişmesi, verilecek değer eğitiminin kalitesine bağlıdır. Bu değer eğitiminin en önemli unsuru ise kanaatimizce sağlıklı din eğitimidir. Çocukta şahsiyet ve dürüstlük ahlakının gelişmesinde dinin üstleneceği rol, küçümsenmeyecek kadar önemlidir (konu hakkında bk. Bilgin, 2000). 


\section{Sonuç}

Bu çalışmada, çocuğun cezâî ehliyetinin tarihî süreçteki gelişimine İslâm ve Osmanlı hukuku ile çağdaş Türk hukuku çerçevesinde değinilmiştir.

Tarihî süreçte yapılan ictihadların, mâlî ve cezâî açılardan çocuk haklarını korumaya yönelik bir yapıya sahip olduğu; kendi dönemlerinde İslâm hukukçularının emsallerine nazaran ileri bir hukuk anlayışı gösterdikleri görülmektedir. Nitekim Maveraünnehir bölgesinde yaşamış bir Hanefî fakihi olan Mecdüddin Üsrûşenî'nin (ö. 632/1235) VII/XIII. asrın başlarında İslâm Hukuku'nda çocuklara müteallik haklar ve yükümlülükler konusunda müstakil bir eser telif etmiş olması, bu konudaki ileri aşamayı ifade etmektedir.

Netice itibarıyla; ceza hukuku açısından bakıldığında, çocuğun cezâî ehliyeti yoktur. Hâlihazırdaki hukuk sistemlerinde ve çeşitli ülkelerde, çocukta ceza ehliyet yaşı farklılık arz etmekle birlikte, bu konu temelde çocukluk yaşının sona erişiyle ilgilidir. İslâm hukuku açısından da durumun farklı olmadığı, muhtelif ictihadlar bulunmakla birlikte, ağır cezalar için en erken ceza ehliyet yaşının 15 yaş olduğu görülmektedir. 15-18 yaş arası çocuk suçlarında ise ülkemizde ve bazı İslâm ülkelerinde cezada indirime gidildiği ve bu dönemin cezayı tahfif sebebi sayıldığı görülür. 


\title{
Criminal Responsibility for Children in terms of Islamic and Positive Law
}

\author{
Murat Şimşek*
}

\begin{abstract}
Although research regarding a child's criminal ahliyah is limited, there are studies, such as Mecdüddîn Üsrûşenî's (632 H/1235 CE) work Ahkāmu's-sığär (I-II, Cairo, undated) which is a study of provisions for children. Today, the most important work directly related to the subject is a PhD thesis titled, "Kentte Suça Karışmış Çocuklarda Toplumsal Ortam ve Ceza Ehliyeti Araştırmaları"/Social milieu of juvenile delinquency in urban and legal capacity research" prepared by Eylem Ümit in the Ankara University Faculty of Law. Another topic directly related to the subject is the article "Eski Devirlerde ve İslâm'da Yaşın Cezaî Mesuliyet Üzerindeki Tesiri" prepared by Naci Şensoy. The latest work directly related to this subject is an article called "islâm Hukukunda Ceza Ehliyeti Açısından Yaş Küçüklüğü/ Childhood in the Context of Criminal Capacity" prepared by Mücahit Çolak as a result of his own doctoral studies. Indirectly, a number of research projects in their infancy are also available. For example, two PhD dissertations prepared by the Mücahit Çolak within the framework of his study "islam Hukukunda Ceza Ehliyetini Etkileyen Durumlar/The Issue of Criminal Legal capacity in Islamic Law" and Talip Atmaca's study "İslam Hukukunda Ceza Ehliyeti/Criminal Liability in Islamic Law." Another study, by Ümit Karslı, is available in his Master's thesis titled "Mezheplere Göre Ceza Ehliyeti ve Günümüz Hukukuyla Mukayesesi/Criminal Liability According to The Madhhabs and its Comparison with Modern Law."
\end{abstract}

A few indirect research projects under discussion during the modern period in the Arab world should also be mentioned. Among these projects those refutable Kubeysi's book es-Sağir beyne ehliyyeti'l-wucūb ve ehliyyeti'l-edā and Huseyin Taufiq Rida's book Ehliyyetü'l-'uqūbe fi'ş-şerī'ati'l-Islämiyye wa'l-qānūni'l- muqäran and Jebūrī's research Awārıdu'l-ehliyye 'inde'l-usūliyyīn.

In the modern, especially Western, world, childhood covers an extended period of time ranging from the instance of birth until the age of eighteen. However, the term "child" differs depending on which legal understanding one uses. In Islamic law, the period before puberty is understood to be the age of childhood. Anyone of this age is considered to be a child (Ali Haydar, 1330, p. III, 9; Aydın, 1993, p. VIII, 361).

* Assist. Prof., Çanakkale Onsekiz Mart University Department of Basic Islamic Sciences, Islamic Law Correspondence: muratsimsek@comu.edu.tr, Çanakkale Onsekiz Mart Üniversitesi İlahiyat Fakultesi Terzioğlu Yerleşkesi, Çanakkale, Turkey. 
Among the countries of the world, there are two approaches in determining the minimum age limit of criminal liability. One approach dictates that a definite age must be specified in limiting the age which one is not criminally liable. The other approach determines criminal liability as being a judicial ruling. For example, certain countries have accepted different legal ages at which criminal liability begins. Among these are the ages of 18 in France; 16 in Denmark, Spain, and Finland; 14 in Switzerland, Italy, and Germany; and 13 in Bulgaria.

Mejelle is one of the legal texts regarding the concept of childhood in Islamic law. In it, childhood is separated into two main parts. These are, "A minor of imperfect understanding is a young person who does not understand selling and buying, that is to say, who does not understand that ownership is lost by sale and acquired by purchase, and who is unable to distinguish obvious flagrant misrepresentation, that is misrepresentation amounting to five in ten, from minor representation. A minor who can distinguish between these matters is called a young person of perfect understanding." (Article 943) (for an English translation, see: http://www.iium.edu.my/deed/lawbase/al_majalle/al_majalleb09.html)

On many issues, Islamic jurisprudence regarded the reaching of puberty as determining one's criminal liability (ahliyah). However, this is not the same as the body's biological development, and legislators have therefore needed to determine an objective criterion. As a result, in addition to sexual development, an individual's intellectual development is taken into consideration (Erbay, 1998, pp. 4-5). This topic is regulated as follows in the Mejelle: "Puberty is proved by the emission of seed during dreams, by the power to make pregnant, by menstruation, and by the capacity to conceive." (Article, 985). Indeed, there are also evidences in the Qur'an: "To those weak of understanding give not your property which Allah has assigned to you to manage, but feed and clothe them therewith, and speak to them words of kindness and justice" (Surah ul-Nisa 4:6) (http://www. kuranikerim.com/english/4.html). This verse (ayah) indicates sexual development.

Historically in the Western world, a child's criminal liability is divided into three periods; the first being the ancient Greek and Roman period, in which a child was under his father's absolute authority, the second being the medieval period, in which religious authority was given precedence, and the third, the modern State period. (Ümit, 2006, p. 7).

Historically in the Islamic world however, the regulations for criminal liability have been determined depending on the age which a child reaches puberty. These years have ranged from 9, 15, 17, and 18 years of age (Şensoy, 1947, s. 517; Ümit, 2006, p. 13).

The Ottoman application is based on the Fatih Code/Fatih Kānunnāmesi, Statutory Criminal Code/ Kanuni Ceza Kānunnāmesi, Sultan İbrahim Code/ Sultan İbrahim Kānunnāmesi, The Fourth Murat Code/Dördüncü Murat Kānunnāmesi and the codes held after the Tanzimat period. The French Penalty Code of 1810 was prepared and effectuated in Ottoman lands in $1858(1274$ H) by Kānunnāmesi-i Humāyun (Atılgan, 2009, p. 13; Şensoy, 1947, p. 524; Ümit, 2006, p. 13-14; 23-24). 
There is no consensus regarding the upper limit of the age of puberty in Islamic law. This topic is regulated as follows in the Mejelle: The commencement of the age of puberty in the case of males is twelve years completed and in the case of females nine years completed. The termination of the age of puberty in both cases is fifteen years completed. If a male on reaching twelve have not arrived at the age of puberty, they are said to be approaching puberty until such time as they do in fact arrive at the age of puberty. (Article 986). This is the majority view. However, Ebû Hanîfe (d. 150/767) accepted the upper limit for the age of puberty to be 18 for females and 17 for males. Ottoman Family Law I Hukuk-ı Aile Kararnâmesi was arranged in accordance with the opinion of the Ebû Hanīfe. (Erbay, 1998, pp. 6-7; Dağcı, 1996, p. 96).

In the Mejelle, childhood is addressed in the context of the law of obligations. This code includes important provisions for a child's legal status in terms of the Islamic legal perspective.

According to Islamic Law, effective spending is not restricted (hacir)and a child is held accountable in terms of financial penalty and compensation. This topic is detailed as follows in the Mejelle: "Minors, lunatics and imbeciles are ipso facto interdicted." (Article, 957) "Any disposition of property such as sale and purchase on the part of interdicted persons referred to it in the preceding Articles, is invalid. Such persons, moreover, must immediately make good any loss caused by their own acts. Example: If $A$, even though he may be a young person of imperfect understanding, destroys property belonging to $B$, he must make good the loss." (Article, 960). "A minor of imperfect understanding may not in any manner make any valid disposition of his property, even though his tutor assents thereto." (Article 966). "Any disposition of property entered into by a minor of imperfect understanding, which is purely for his own benefit, such as the acceptance of gift and presents, is valid, even though his tutor does not assent thereto. Any disposition of property, however, which is purely to his own disadvantage, such as bestowing a thing upon another by way of gift, is invalid, even though the tutor assents thereto. But in the case of contracts where it is not certain whether they will be for his benefit or disadvantage, such contracts are concluded subject to the permission of the tutor. The tutor has the option of giving or withholding his consent. Thus, if he thinks that it is to the advantage of the minor, he will give his consent, and not otherwise. Example:- A minor of perfect understanding sells certain property without permission. The execution of the sale is subject to the assent of his tutor, even though he has sold it for a price which is greater than the value thereof, the reason being that the contract of sale is one where it is not certain whether it will be for his advantage or disadvantage." (Article 967). "Tutor may give a minor of perfect understanding a portion of his property on trial with which to engage in business, and if it turns out as a result that he is of mature mind, he may deliver him the balance of such property." (Article 968). "When permission is given to a minor by his tutor, such minor is considered to have arrived at the age of puberty in respect to the matters included in the permission. Contract such as those relating to sale and hire are valid." (Article, 972). 
The term criminal liability is understood to be liable to penalty. The concept of "ascription to ability" created the basis for criminal liability. (Artuk-Gökcen-Yenidünya, 2002, p. I, 538-544; Çolak, 2011, p. 108-109; Dönmezer-Arman, 1999, p. II, 145; Karslı, 2006, p. 42; Ümit, 2006, p. 2).

Islamic jurists have determined that for an action to be constituted as a crime necessitating legal penalty an adolescent must have pubic hairs. Islamic lawyers have suggested that it is essential that an adolescent be of sound mind for an action to be able to be considered a crime. In this respect, they have agreed that the element of intention is required for criminal liability to be applicable for an offence (Avcl, 2004, p. 125; Çeker, 1990, p. 209-214; Erbay, 1998, p. 80-81; Ûdeh, 1987, p. I, 602-604). In accordance with the principle of "religious/legal excuses do not eliminate the sanctity of property," a child is still held to be civilly responsible for reimbursement. (Dağcl, 1996, p. 20, 96). This topic is regulated as follows in the Mejelle: If a minor destroys the property of another, he must make good the loss thereof out of his own property. If he is not possessed of any property, payment may be postponed until he is in a position to pay. His tutor may not be called upon to make good the loss. (Article, 916).

In Turkish Criminal law, the stages of a child's liability are as follows:

(1) Children whose age is under 12 years at the time of the deed cannot be penalized. There can be no criminal prosecution, however safety measures specific to children can be applied (Article 31).

(2) If above the age of 12 years but under the age of 15 years and if not perceiving the legal meaning and consequences of his act or not having a sufficient capacity of selfdetermination, there is no criminal liability. However safety measures specific to children can be taken. If able to understand his deed and having self-determination regarding this deed, their penalty will be reduced: aggravated life sentence to a penalty of nine to twelve years, life sentence to a penalty of seven till nine years. Other penalties will be reduced by two third, in this case the maximum penalty for each deed will be maximum six years.

(3) If at the time of performing the deed a person has already reached the age of fifteen years but not the age of eighteen years, his penalty will be reduced: aggravated life sentence to a penalty of fourteen to twenty years, life sentence to a penalty of nine till twelve years. Other penalties will be reduced by one half, in this case the maximum penalty for each deed will be maximum eight years.

In today's society, the absence of child's criminal responsibility is exploited by certain individuals or criminal organizations. It is important to respect the rights of a child when applying any sanction. The current Child Protection Act (5395) uses the concept of "the child pushed to crime" instead of "guilty child."

Article 1- (1) The purpose of this Law is to regulate the procedures and principles with regard to protecting juveniles who are in need of protection or who are pushed to crime, and ensuring their rights and well-being. 
Article 2- (1) This Law covers the provisions related to the principles and procedures of the measures that will be taken with regard to juveniles who are in need of protection and the safety measures to be applied with regard to juveniles pushed to crime, along with the establishment, duties and capacities of juvenile courts. Juvenile in need of protection: Any juvenile whose physical, mental, moral, social or emotional development and personal safety is in danger, who are neglected or abused, or who are victims of crime, (Article 3.a/2). (See http://freedownload.is/pdf/child-protectionlaw-18914014.html).

As far as criminal law is concerned, there is no criminal liability for child. However, among the countries of the world, the age at which criminal liability begins is different. This topic is basically related to the end of the age of childhood. The situation is no different than Islamic law. Although there are different case laws, the earliest age for criminal liability for heavy penalties begins at the age of 15. In Turkey, as well as other countries in which Islam is the majority religion practiced, penalty reductions are given for individuals between the ages of 15-18.

\section{Kaynakça / References}

Adams, R. (1993). Çocuk hukuku ve çocukların, gençlerin hakları. B. Franklin (der.), Çocuk hakları (çev. A. Türker, s. 114-141) içinde. İstanbul: Ayrıntı Yayınları.

Ali Haydar Efendi. (1330). Dürerü'I-hukkâm şerhu Mecelleti'l-ahkâm I-IV. Kostantiniye: Matbaa-i Ebu'z-Ziyâ. Artuk, M. E., Gökcen, A. ve Yenidünya, A. (2002). Ceza hukuku genel hükümler I-Il. Ankara: Seçkin Yayıncılık. Atılgan, A. ve Eylem, Ü. (2009). Çocuk hakları paradigması ve çocuk ceza yargılamasına hâkim olan ilkeler açısından Türkiye'deki düzenleme ve uygulamaların değerlendirilmesi. http://ihop.org.tr/dosya/cocukhaklari.pdf adresinden 28/09/2010 tarihinde edinilmiştir.

Atmaca, T. (2002). İslâm hukuku'nda ceza ehliyeti. Ankara Üniversitesi Sosyal Bilimler Enstitüsü Temel İslâm Bilimleri, (Yayımlanmamış Doktora Tezi).

Avcı, M. (2004). Osmanlı hukukunda suçlar ve cezalar. İstanbul: Gökkubbe Yayınları.

Avcı, M. (2005). Çocuk suçları konusundaki mevzuatın değerlendirilmesi. Çocuk sorunları ve İslâm Sempozyumu-Rize, (s. 352-395) içinde. İstanbul: Ensar Neşriyat.

Aydın, M. A. (2009). Türk hukuk tarihi. İstanbul: Beta Yayınları.

Aydın, M. A. (1993). "Çocuk". Diyanet İslâm Ansiklopedisi (c. VIII, s. 361-363) içinde. İstanbul: ISAM.

Bardakoğlu, A. (1993). "Ceza”. Diyanet İslâm Ansiklopedisi (c. VII, s. 470-478) içinde. İstanbul: İSAM.

Bardakoğlu, A. (1994). "Ehliyet". Diyanet İslâm Ansiklopedisi (c. X, s. 533-539) içinde. İstanbul: ISAM.

Bilge, N. (2003). Hukuk başlangıcı. Ankara: Turhan Kitabevi.

Bilgin, B. (2000). İslâm ve çocuk. Ankara: Diyanet Yayınları.

Cebûrî, H. H. (1988). Avârıdu'l-ehliyye 'inde'l-usûliyyîn. Mekke: Merkezü Buhûsi'-Dirâseti'l-i̇slâmiyye.

Centel, N., Zafer, H. ve Çakmut, Ö. (2005). Türk ceza hukukuna giriş. İstanbul: Beta Basım Yayım.

Dönmezer, S., Erman, S. (1999). Nazarî ve tatbikî ceza hukuku I-II. İstanbul: Beta Basım Yayım.

Çeker, O. (1990). İslâm hukuku'nda çocuk. İstanbul: Kayıhan Yayınları.

Çeker, O. (1999). Osmanlı hukuk-ı aile kararnâmesi. Konya: Bilge Sahaf Kitabevi. 
Çiğdem, R. (2005). Çocuk istismar ve ihmali. Çocuk sorunları ve İsâm sempozyumu (s. 183-198) içinde Rize: Ensar Neşriyat.

Çolak, M. (2003). İslâm hukuku'nda ceza ehliyetini etkileyen durumlar. Atatürk Üniversitesi Sosyal Bilimler Enstitüsü Temel İslâm Bilimleri, 2003. (Yayımlanmamış Doktora Tezi).

Çolak, M. (2011). İslâm hukuku'nda ceza ehliyeti açısından yaş küçüklüğü. Atatürk Üniversitesi IIlahiyat Fakültesi Dergisi, 35, 103-124.

Demirbaş, T. (2006). Ceza hukuku genel hükümler. Ankara: Seçkin Yayıncılık.

Erbay, C. (1998). İslâm hukuku'nda küçüklerin himayesi. İstanbul: Rağbet Yayınları.

Franklin, B. (1993). Çocuk hakları (çev. A. Türker). İstanbul: Ayrıntı Yayınları.

Hüseyin Tevfik Rıza. (1964). Ehliyyetü'I-'ukûbe fi'ş-şerî'ati'l-Islâmiyyeve'l-kânûni'l-mukâran. Yayımlanmamış doktora tezi, Kahire Üniversitesi Hukuk Fakültesi, Kahire.

Işık, E. (2007). Kent yoksulluğu, sokak çocukları ve suç. Yayımlanmamış yüksek lisans tezi, Dumlupınar Üniversitesi, Kütahya.

İbn Kayyim el-Cevziyye. (1983). Tuhfetü'l-mevdûd bi-ahkâmi'l-mevlûd. Beyrut: Dârü'l-Kütübi'I-illmiyye.

Karslı, Ü. (2006). Mezheplere göre ceza ehliyeti ve günümüz hukukuyla mukayesesi. Yayımlanmamış yüksek lisans tezi, Kahraman Maraş Sütçü İmam Üniversitesi.

Köse, S. (2005). İslâm hukuku'nda çocuğun çalışması, gelirinin korunması ve istismarını önleyici tedbirler. Çocuk Sorunları ve İslâm Sempozyumu (s. 117-159) içinde Rize: Ensar Neşriyat.

Kubeysî, Mahmûd Mücîz b. Su'ûd. (1981). es-Sağîr beyne ehliyyeti'l-vucûb ve ehliyyeti'l-edâ. Mekke: Câmi 'atü Melik Su'ûd.

Medkûr, M. S. (1969). el-Cenîn ve'l-ahkâmü'l-müte'allika bihî fi'l-fikhi'l-Islâmî. Kahire: Dârü'n-Nehdati'lArabiyye.

Okumuş, E. (2005). Çocuk suçluluğunun önlenmesi ve İslâm. Çocuk Sorunları ve İsâm Sempozyumu (s. 396-432) içinde. Rize: Ensar Neşriyat.

Şafak, A. (2005). Çocukların suç aleti olarak istismarının sebepleri ve önlemleri bağlamında çocukların tecziyesi sorunu. Çocuk Sorunları ve İslâm Sempozyumu (s. 325-351) içinde. Rize: Ensar Neşriyat.

Şensoy, N. (1947). Eski devirlerde ve İslâm'da yaşın cezaî mesuliyet üzerindeki tesiri. İstanbul Üniversitesi Hukuk Fakültesi Mecmuası, XIII (2), 513-528.

Tiryakioğlu, B. (1991). Milletlerarası özel hukukta çocuklara ilişkin kurallar. Ankara: Başbakanlık Aile Araştırma Kurumu Yayınları.

Ûdeh, A. (1987). et-Teşrî́'u' I-cinâiyyi'l-Islâmî l-II, Beyrut: Dârü'n-Kâtibü'I-Arabi.

Uzunpostalcı, M. (2006). İslâm hukuku açısından ehliyet. İslâm Hukuku Araştırmaları Dergisi, 8, 149-182.

Ümit, E. (2006). Kentte suça karışmış çocuklarda toplumsal ortam ve ceza ehliyeti araştırmaları. Yayımlanmamış doktora tezi, Ankara Üniversitesi Hukuk Fakültesi.

Üsrûşenî, M. (t.y.). Câmi'u ahkâmi's-sığâr, I-II. Kahire: Dârü'I-Fazile.

Yelesdağ, H. (2006). Ceza hukukunda çocuk kavramı ve ceza sorumluluğunun belirlenmesindeki kriterler. Yayımlanmamış yüksek lisans tezi, Marmara Üniversitesi, Hukuk Fakültesi, İstanbul.

Zerkâ, M. A. (1998). el-Medhalü'l-fıkhî el-'âm, I-Il. Dımaşk: Dârü'l-Kalem. 